\title{
EFFECT OF FOLIAR SPRAYING BY CHELATING IRON ON TECHNOLOGICAL TRAITS AND NUTRITIONAL VALUE OF FABA BEAN SEEDS
}

\section{SHABAN M. SOLIMAN}

Food Technology Res. Institute, ARC, Giza .

(Manuscript received 24 May 2011)

\begin{abstract}
To investigate the influence of foliar spraying with chelating iron on technological traits, nutritional value and yield of produced faba bean seeds, thus, two field experiments were conducted at Sers El-layian Agric. Res. St. farm. In the two successive seasons 2008 and 2009. Plants were sprayed by chelating iron (EDTA) at concentrations $0.04 \%$ and $0.08 \%$ and / or without sucrose $0.4 \%$ as foliar fertilizer. Application of EDTA $0.08 \%$ was more effective than EDTA $0.04 \%$. Addition of sucrose $0.4 \%$ increased improvement of all evaluated traits. Stewing percentage reached $100 \%$, imbibed water after soaking : $97.2 \%$, seed density $1.62 \%$ and T.S.S. : 7.19\% . : Protein content reached 29.46\% , K, Ca , $\mathrm{Mg}, \mathrm{Fe}, \mathrm{Zn}$, and $\mathrm{Mn}$ showed maximum contents of 1102.6, 56.81, $91.04,9.17,4.35$ and $1.232 \mathrm{mg} / 100 \mathrm{~g}$ sample(D.W.B.) respectively

(c) Productivity recorded : seed yield $13.67 \mathrm{t} / \mathrm{fed}$. And weight of 100 seeds : $77.57 \mathrm{~g}$.
\end{abstract}

\section{INTRODUCTION}

Faba bean seeds have high nutritional value and are used as human food in developing countries where it is utilized as a vegetable either green or dried, fresh or canned .

Faba bean is a common staple food in the Egyptian diet . the most popular dishes of faba bean are Medamis (stewed beans), Flafel(deep fried cotyledon paste with some spices), Bissara (cotyledon paste poured on to plates) and Nabet soup (boiled germinated beans ) .

It is a traditional breakfast food in the Middle east, Mediterranean region , China and Ethiopia (Jambunathan et. al. , 2007) .

Area cultivated with broad bean in Egypt is about 175 thousand feddans. Its productivity reached 1.363 ton / fed. (MALR 2010) . 
Determination of proximate chemical composition in the dry matter of seeds of four faba bean cultivars by ( ElMaki et. al., 2005) showed the following : crude protein : $29.5 \%$, fibre : $5.7 \%$, oil : $1.3 \%$, ash : $3.3 \%$ and carbohydrates $54.2 \%$

Some macro and micronutrients of faba bean seeds were determined by (ElMaki et. al. , 2005 ). The obtained data (mg/ 100g sample DWB ) revealed that:

$\mathrm{Na}: 27, \mathrm{~K}: 1037, \mathrm{Mg}: 255$, Ca : 427 and $\mathrm{P}: 197, \mathrm{Fe}: 6.1$

$\mathrm{Zn}: 2.2, \mathrm{Mn}: 3.2$ and $\mathrm{Cu}: 0.7$.

Selected physical properties of 2 small-seed broad bean varieties determining their technological quality, were studied comparing with large-seed varieties. The study involved the determination of 1000 seeds mass, percentage of seed coat and water holding capacity. It was pointed out that the small-seed varieties were more suitable for technological processing . (Giczewska and Borowska 2007) .

Foliar fertilization or foliar feeding entails application - via spraying - of nutrients to plant leaves and stems and their absorption at those sites. Foliar application of micronutrients will normally result in a rapid response if a deficiency exists. Also a response can be obtained with less material than in soil application .In terms of nutrient absorption, foliar fertilization can be from 8 to 20 times as efficient as ground application. Use of foliar fertilization requires determination of need, possible benefits and what materials to apply ( Faulkner , 2006 ) .

Iron is an important nutrient, and it plays a wide range of vital roles in the human body including the transport and storage of oxygen from lungs to muscles and other cells. It is needed for synthesis of hemoglobin, it is very essential in energy production and it is required by white blood cells to fight infections (Rossander and hallberg, 2004 ).

Chelated iron is simply iron that has undergone chelation, a chemical process that firmly binds the iron molecule to another substance, usually an amino acid. This forms a more stable ring - shaped molecule that is easier for plants and animals to absorb (Welkie and Miller, 2002 ).

the present study aimed to evaluate the effect of foliar application of chelating iron on the technological properties, nutritional value and yield of faba bean seeds.

\section{MATERIALS AND METHODS}

\section{Materials :}

This work was carried out at the Agricultural Experimental Station Farm of Sers El-Lyian , Menofia governorate, Egypt , during the two successive seasons 2008 and 2009 , to search the influence of foliar spraying with chelating iron on technological traits, nutritional value and yield of faba bean seeds (Egyptian 1) 
Physical and chemical properties of soil were analyzed before sowing .

Four replicates were employed where the total plots were 24 , each one has an area of $10.5 \mathrm{~m}^{2}(3 \times 3.5)$.

Foliar spraying was performed with chelating iron at concentration $0.04 \%$ and $0.08 \%$ in the form of EDTA (Ethelynediaminetetraacetic acid ) with or without sucrose solution( $0.4 \%$ ). Sucrose solution $\left(0.4 \%\right.$ ) alone was employed as the $6^{\text {th }}$ treatment .

The mentioned treatments were applied at 35 and 60 days after planting . After maturity, plants were harvested and the seed yield of each treatment was mixed together and a representative samples were taken for analysis .

\section{Methods :}

\section{I _ Physical and cooking properties :}

The whole seeds without milling were used for determination of physical properties ( density , imbibed water \% and hull / seed percentage ) and cooking properties according to (Fahmy et. al. , 1996 ) .

- $\quad$ seeds were soaked in tap water for (12 hrs. )

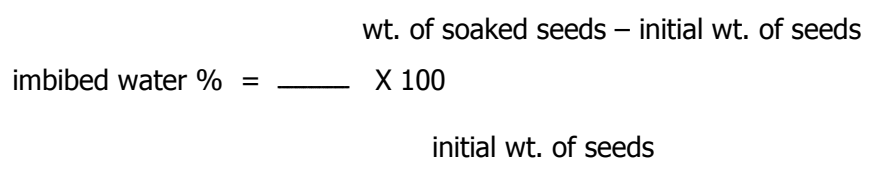

After soaking time (12 hrs. ) seeds were dehulled then the seed coats (hulls) and cotyledons were dried in an oven (60 $\mathrm{C}^{\circ} / 12 \mathrm{hrs}$. ) and weighted to calculate hull / seed \% .

Water soluble materials or total soluble solids (TSS ) : the cooking water containing soluble materials was poured into porcelain pot and placed in an oven at $60 \mathrm{C}^{\circ}$ until all cooking water evaporates .

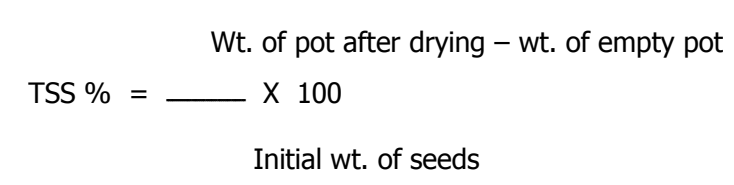

Cookability : the stewing of cooked seeds was measured by normal press by fingers on cooked seeds and comparing between their hardness and softness .

\section{II - Chemical analysis :}

Oil content, total proteins and ash contents were determined according to A.O.A.C. ( 2005 ). 
Total carbohydrates were colorimetrically determined by the phenol - sulfuric method that outlined by Doubois et. al. (1956).

Mineral contents $(\mathrm{K}, \mathrm{Na}, \mathrm{Ca}, \mathrm{Mg}, \mathrm{Zn}, \mathrm{Fe}$ and $\mathrm{Mn})$ were determined after ashing the faba bean whole meal and dissolving in known volume of sulphuric acid $(0.1 \mathrm{~N})$, by Berkin-Elmer Atomic Absorption Spectrophotometer 3300 as described in A.O.A.C. (2005).

Statistical analysis : the obtained data were subjected to statistical analysis according to the procedures of Steel and Torri (1980) .

\section{RESULTS AND DISCUSSION}

\section{I - Consequence of EDTA foliar feed in regards chemical composition of faba bean seeds .}

Data recorded in table (1) indicate that spraying of faba bean plants with chelating iron enhanced protein content in the produced seeds until $28.54 \%$ in case of (EDTA $0.08 \%$ ) . Furthermore, the maximum protein content 29.46 was due to application of (EDTA $0.08 \%+$ sucrose $0.4 \%$ ). This treatment also led to the highest contents of : oil (3.54\% ), ash (4.35\%) and total carbohydrates (56.47\%).

Foliar spraying with sucrose $0.4 \%$ enhanced the technological traits less than all EDTA treatments while the control treatment (spray with water) led to the lowest technological traits values in all treatments.

Table 1. chemical composition of faba bean seeds obtained from foliar - chelating iron fertilized plants ( on d.w.b. )*

\begin{tabular}{|l|c|c|c|c|}
\hline Treatments & Protein \% & Oil \% & Ash \% & $\begin{array}{c}\text { Total } \\
\text { carbohydrates } \\
\%\end{array}$ \\
\hline 1- Control (spray by water) & 23.83 & 1.77 & 2.92 & 61.86 \\
2- EDTA (0.04 \%) & 25.31 & 2.63 & 3.46 & 61.38 \\
3- EDTA (0.04 \%) + sucrose $0.4 \%$ & 27.45 & 2.37 & 3.34 & 60.05 \\
4- EDTA 0.08\% & 28.54 & 2.83 & 3.82 & 57.65 \\
5- EDTA 0.08 \%+ sucrose $0.4 \%$ & 29.46 & 3.54 & 4.35 & 56.47 \\
6- Sucrose 0.4\% & 24.90 & 1.94 & 3.06 & 60.92 \\
\hline
\end{tabular}

(*) d.w.b.

: on dry wiet basis

$(* *)$ Treatment data $\quad$ : mean of three replicates . 
The results in table (1) agree with that obtained by many researches who proved that iron is necessary for production of chlorophyll and photosynthesis process which result in increase of protein biosynthesis . iron also takes part in nodule formation and function, thus, it is necessary for nitrogen fixation that leads to increase protein biosynthesis ( Welkie and Miller, 2002).

Results of table (2) indicate that the most important technological traits of faba bean seeds were directly proportionated with concentration of sprayed chelated iron (EDTA). Maximum values of stewing, water imbibition and T.S.S. percentage were obtained in case of treatment with ( EDTA $0.08 \%+$ sucrose $0.4 \%$ ), the obtained values were $100 \%, 97.2 \%$ and $7.19 \%$ respectively .

The highest seed density $\left(1.62 \mathrm{~g} / \mathrm{cm}^{3}\right)$ obtained in case of the same treatment . Hull / seed ratio was inversely proportionated with the chelated iron concentration minimum hull /seed ratio $12.5 \%$ was recorded in case of (EDTA $0.08 \%+$ sucrose 0.4 $\%)$.

Spraying with sucrose $0.4 \%$ enhanced the technological traits less than all EDTA treatments, while, control treatment (spraying with water )led to the lowest technological traits values in all treatments . From each of the above, using of (EDTA $0.08 \%$ + sucrose $0.4 \%$ ) leads to production of faba bean seeds with the most preferred technological traits .

Table 2. Influence of chelating iron on physical and technological traits of faba bean seeds produced from foliar - sprayed plants .

\begin{tabular}{|c|c|c|c|c|c|}
\hline Treatments & $\begin{array}{c}\text { Density g / } \\
\mathrm{cm}^{3}\end{array}$ & $\begin{array}{c}\text { Hull /seed } \\
\%\end{array}$ & $\begin{array}{l}\text { imbibed water } \\
\text { after soaking } \%\end{array}$ & $\begin{array}{c}\text { Stewing } \\
\%\end{array}$ & T.S.S. \% \\
\hline $\begin{array}{l}\text { 1- Control } \\
\text { (spraying } \\
\text { by water ) }\end{array}$ & 1.23 & 14.37 & 82.17 & 84 & 4.81 \\
\hline 2- EDTA (0.04\%) & 1.40 & 13.64 & 92.38 & 92 & 5.98 \\
\hline $\begin{array}{l}\text { 3-EDTA }(0.04 \%) \\
\quad \text { +sucrose } 0.4 \%\end{array}$ & 1.57 & 13.52 & 94.14 & 95 & 6.12 \\
\hline 4-EDTA $(0.08 \%)$ & 1.59 & 13.46 & 96.75 & 96 & 6.61 \\
\hline $\begin{array}{l}\text { 5-EDTA }(0.08 \%) \\
\quad \text { +sucrose } 0.4 \%\end{array}$ & 1.62 & 12.25 & 97.20 & 100 & 7.19 \\
\hline 6 - sucrose $0.4 \%$ & 1.35 & 14.11 & 84.59 & 86 & 5.45 \\
\hline LSD at $5 \%$ & 0.2402 & 0.33656 & 0.8468 & 3.58109 & 0.3243 \\
\hline
\end{tabular}

$(*)$ T.S.S. $\quad$ : total soluble solids

$(* *)$ treatment data : mean of three replicates 
Addition of sucrose $0.4 \%$ to EDTA $0.08 \%$ for foliar application attained the maximum improvement of technological characters . this illustrated by (Arzani et. al. , 2004 ) who mentioned that a mixture of carbohydrates (3\% sucrose , $2 \%$ glucose and $0.5 \%$ fungicide of copper oxychloride ) was absorbed by leaves of pistachio through foliar application whereby the nut quality highly improved .

As shown in table (3) :The more applied EDTA concentration is increasing contents of $\mathrm{K}, \mathrm{Na}$, $\mathrm{Ca}$ and $\mathrm{Mg}$ in faba bean seeds . Best potassium value 1102.6 (mg/ $100 \mathrm{~g}$ sample ) was obtained via treatment No.5 (EDTA $0.08 \%+$ sucrose $0.4 \%$ ) where the $(K)$ value exceeded twice of the $(K)$ value of control $(445.26 \mathrm{mg} / 100 \mathrm{~g}$ sample ).

In the same way, the highest magnesium content $(91.04 \mathrm{mg} / 100 \mathrm{~g}$ sample ) was obtained via treatment $\mathrm{No} .5$ where the $\mathrm{Mg}$ content exceeded twice of the $\mathrm{Mg}$ content of control $(43.6 \mathrm{mg} / 100 \mathrm{~g})$. Highest $\mathrm{Ca}$ and $\mathrm{Na}$ values also were obtained via the same important treatment.

Table 3. Influence of foliar spraying with chelating iron on some macro elements content in faba bean seeds ( $\mathrm{mg} / 100 \mathrm{~g}$ on $\mathrm{dwb}^{*}$ ).

\begin{tabular}{|c|c|c|c|c|}
\hline Treatments ${ }^{* *}$ & K & $\mathrm{Na}$ & $\mathrm{Ca}$ & $\mathrm{Mg}$ \\
\hline $\begin{array}{l}\text { 1- Control (spray by } \\
\text { water ) }\end{array}$ & 445.26 & 17.34 & 46.06 & 43.60 \\
\hline 2- EDTA (0.04\%) & 708.66 & 23.45 & 50.06 & 69.47 \\
\hline $\begin{array}{l}\text { 3- EDTA }(0.04 \%)+\text { sucrose } \\
0.4 \%\end{array}$ & 778.93 & 30.26 & 50.59 & 79.62 \\
\hline 4- EDTA (0.08 \%) & 956.6 & 41.25 & 52.64 & 86.07 \\
\hline $\begin{array}{l}\text { 5- EDTA }(0.08 \%)+\text { sucrose } \\
0.4 \%\end{array}$ & 1102.6 & 48.13 & 56.81 & 91.04 \\
\hline 6- Sucrose $0.4 \%$ & 680.27 & 23.11 & 49.46 & 67.97 \\
\hline LSD at $5 \%$ & 16.6740 & 1.1080 & 2.0238 & 1.56796 \\
\hline
\end{tabular}

Iron is an essential nutrient for plant growth and development . It is involved in nitrogen fixation, where, it takes part in initiation, development and function of nodules ( Hansen et. al. ,2008 ) . Bacterial Cells in nodules on the host roots have diversity of extracellular enzymes , the most potential that these enzymes convert 
complicated mineral substances in the rhizosphere area to soluble state, so these bacteria are active in uptake of many elements and supply plant with them, also due to activity of these enzymes in soil around roots, many elements become more available to be absorbed by plant itself .

Based on the above, foliar feeding with chelating iron leads to the increase of mineral contents in the produced faba fean seeds.

Data represented in table (4) revealed that iron percentage in seeds of control samples was $(5.41 \mathrm{mg} / 100 \mathrm{~g}$ ) whereas iron percentage increased up to $(9.17 \mathrm{mg}$ $/ 100 \mathrm{~g}$ ) due to application of treatment (EDTA $0.08 \%+$ sucrose $0.4 \%$ ). Zinc content in seeds exhibited maximum value $(4.35 \mathrm{mg} / 100 \mathrm{~g})$ as a result of treatment with (EDTA $0.08 \%+$ sucrose $0.4 \%$ ). The same treatment improved manganese content in faba bean seeds up to $1.232 \mathrm{mg} / 100 \mathrm{~g}$ but that of control was $0.713 \mathrm{mg} / 100 \mathrm{~g}$.

Table 4. Influence of foliar spraying by chelating iron on some micro elements content in faba bean seeds (mg / $100 \mathrm{~g}$ on DWB $)^{*}$.

\begin{tabular}{|c|c|c|c|}
\hline Treatments** & $\mathrm{Fe}$ & $\mathrm{Zn}$ & $\mathrm{Mn}$ \\
\hline $\begin{array}{c}\text { 1- Control (spraying by } \\
\text { water ) }\end{array}$ & 5.41 & 2.37 & 0.713 \\
\hline 2- EDTA (0.04\%) & 7.55 & 2.83 & 0.963 \\
\hline $\begin{array}{c}\text { 3- EDTA }(0.04 \%)+ \\
\text { sucrose } 0.4 \%\end{array}$ & 8.24 & 3.28 & 1.0 \\
\hline 4- EDTA (0.08 \% ) & 8.34 & 3.59 & 1.19 \\
\hline $\begin{array}{c}\text { 5- EDTA }(0.08 \%)+ \\
\text { sucrose } 0.4 \%\end{array}$ & 9.17 & 4.35 & 1.232 \\
\hline 6- Sucrose $0.4 \%$ & 6.55 & 2.64 & 0.826 \\
\hline LSD at $5 \%$ & 1.42707 & 0.42836 & 0.32139 \\
\hline
\end{tabular}

(*) DWB : Dry weight base

$(* *)$ Treatment data : mean of three replicates .

This finding agree with that reported by (El-Hamdi , 2003 ) who mentioned that foliar feeding of combined treatment of $\mathrm{NH}_{4} \mathrm{NO}_{3}+$ chelated forms of $\mathrm{Fe}, \mathrm{Mn}$ and $\mathrm{Zn}$ for broad bean , increase the crop yield and $\mathrm{N}, \mathrm{Fe}, \mathrm{Mn}$ and $\mathrm{Zn}$ in both leaves and seeds, but did not influence $P$ and $K$ contents . 
Rengel et. al. (2006 ) cited that increased micronutrient density in grain and seed destined for human consumption may alleviate micronutrient deficiencies (Fe , $\mathrm{Zn}, \mathrm{Cu}$ and I ) in human populations around the worled. The review of literature indicates that fertilization with micronutrients increases their concentrations in grain and seed . The most effective is the foliar fertilization by iron .

From table (5) : it is clear that the treatment No 5 (EDTA $0.08 \%+$ sucrose $0.4 \%$ ) achieved superior faba bean seed yield (13.67 $t /$ fed. ) compared to (9. 39 t. /fed.) for control (spraying by water) .

The same good treatment No .5 accomplished the maximum weight of 100 seeds $(77.57 \mathrm{~g})$, while that of (control ) was $(59.27 \mathrm{~g})$. Plant height recorded the highest $(115.43 \mathrm{~cm})$ as a result of treatment (EDTA $0.08 \%+$ sucrose $0.4 \%$ ) application. The lowest plant height $(94.13 \mathrm{~cm})$ recorded in case of control .

Table 5. Effect of foliar spraying by chelating iron on productivity of produced faba bean seeds and plant height .

\begin{tabular}{|c|c|c|c|}
\hline \multirow{2}{*}{ Treatments $^{* *}$} & \multicolumn{2}{|c|}{ Faba bean seeds productivity } & \multirow{2}{*}{ Plant height $(\mathrm{cm})$} \\
\hline & Yield $\mathrm{t} / \mathrm{fed}^{*}$ & $\begin{array}{c}\text { Weight of } 100 \text { seeds } \\
(\mathrm{g})\end{array}$ & \\
\hline $\begin{array}{l}1 \text { - control (spraying } \\
\text { by water) }\end{array}$ & 9.39 & 59.27 & 94.13 \\
\hline 2- EDTA $(0.04 \%)$ & 10.10 & 70.79 & 104.21 \\
\hline $\begin{array}{c}\text { 3- EDTA }(0.04 \%)+ \\
\text { Sucrose } 0.4 \%\end{array}$ & 12.04 & 76.05 & 107.21 \\
\hline 4- EDTA $(0.08 \%)$ & 13.59 & 77.42 & 110.35 \\
\hline $\begin{array}{c}\text { 5- EDTA }(0.08 \%)+ \\
\text { Sucrose } 0.4 \%\end{array}$ & 13.67 & 77.57 & 115.43 \\
\hline 6- Sucrose $0.4 \%$ & 9.85 & 60.79 & 100.06 \\
\hline LSD at $5 \%$ & 1.605 & 6.577 & 7.23348 \\
\hline
\end{tabular}

(*) $\mathrm{t} /$ fed. $\quad$ : ton / feddan

(**) Treatment data : mean of three replicates.

These results agree with El-Gizawy (2005) who reported that foliar spraying by fe + Mn significantly increased plant height of faba bean , 100 seeds weight and seed yield per feddan and the protein content of seeds. 
Iron is an essential micronutrient required for plant growth. Iron atom in the cytochrome shuttles between the ferrous and ferric states. Cytochromes are group of special cell proteins that serve energy transfer within the cell.

Moreover $\mathrm{Fe}$ is very necessary for many enzymes in the plant cell and plays an important role in photosynthesis so foliar feeding by iron increases crop yield.

\section{CONCLUSION}

Crops sensitive to iron deficiency include beans, citrus, peanut and soybean. Using of simple iron compound such as iron nitrate causes precipitation with other chemicals, to avoid this we use chelated iron where the chelating agent holds iron tightly so it cannot precipitate. Application of chelated iron promotes iron absorption into the plant.

Iron is essential for many processes in the plant including photosynthesis and respiration, it represents a constituent in many enzymes. Iron plays very important role in energy transfere within the plant.

It is involved in nitrogen fixation where it takes part in initiation, development and function of nodules.

This research indicated the valuable importance of foliar spraying by chelated iron in faba bean crop.

Where, this research exhibited that a significant increase in protein content and contents of certain necessary micro and macroelements that previously mentioned, all these merits were accomplished due to application of ( EDTA $0.08 \%+$ sucrose 0.4 $\%$ ) foliarly.

High improvement in technological traits of the produced seeds including stewing , seed density, water imbibition, seed / coat ratio and T.S.S was attained due to the same above mentioned treatment. The same treatment also attained a significant increase in seed yield

Thus it can be advised that usage of foliar feeding by chelated iron for legume crops particularly faba bean to obtain the cited merits . 


\section{REFERENCES}

1. AOAC 2005 . Official methods of Analysis ( $18^{\text {th }}$ ed.) Association of Official Analytical Chemists. Gaithersburge, MD , USA .

2. Arzani , K. , H. Hokmabadi and Y. S. Dhghani . 2004. Effect of foliar application of some carbohydrates on qualitative and quantitative traits of pistachio nuts. ISHS Acta Horticulturae 594 International symposium of foliar nutrition of perennial fruit plants . v (1) No. 93 Merano, Italy .

3. Doubois , M. , K. A. Gilles , J. K. Hamilton , P. A. Rebers and F. Smith. 1956. :Colorimetric method for determination of sugars and related substances. Anal. Chem., $28: 350$.

4. EL-Gizawy , N. K. B. 2005. Response of some faba bean varieties to foliar fertilization with manganese and iron. Annals of Agricultural Science Moshtohor . 41 ( 4), 1421-1431.

5. EL-Hamdi , A. R. H. 2003. Utilization of nitrogen with some micronutrients as foliar fertilization for broad bean crop . Annals of Agric. Sci, - Moshtohor .37 (3) : $2093-2103$.

6. El Maki , B., M. A. Samia, E. B. El - fadil and E. Abdullahi . 2005 . Proximate composition, Antinutritional factors and miniral content and availability of selected legumes and cereals . J of Food Technology 3(4), 511 :515.

7. Fahmy, H.H., S. Srivastava. and M. A. velerrax. 1996. physical and textural characteristics of soaked and cooked American common beans . Egypt J. Food Sci. , 24 (2) : 1.

8. Faulkner, S. P. 2006 . Foliar feeding when your plants need it fast . The growing Edge. May -June .P. $42-43,47$.

9. Giczewska , A. and J. Borowska. 2007. Physical properties of selected legume seeds as indicators of technological suitability of small - seed broad bean . Polish J. of Food and Nut. Sciences 12 (2):9-13 Poland .

10. Hansen , N. C. , M. A. Schmitt , J. E. Andersen and J. S. Strock. 2008 . Iron deficiency of broad bean in the upper Midwest and associated soil properties. Agron . J ., 95 : $1595-1601$.

11. Jambunathan , R ., H. L. Blain , K . H . Dhindsa , L . A . Hussein , K . Kogure, L. L. Juan and Youssef. 2005 . Diversifying use of Cool season food legumes through processing. PP $98-112$. In : Muehlbaur, .F.J and Kaiser, W.J. (eds.) Expanding the production and use of Cool season legumes . Kluwer Academic Publishers, Dordrecht, The Netherlands . 
12. MALR 2008 . Ministry of Agriculture and Land reclamation. National Program for legume crops . Bulletin No. 988.

13. Rengel, z. , G. D. Batten and D. E. Crowly. 2006 . Agronomic approaches for improving the micronutrient density in edible portions of field Crops. Field Crops Research vol. 60 issues 1-2 , P 27-40.

14. Rossander, H. L. and L. Hallberge. 2004. Prevention of iron deficiency . Amer. J. clinical Nutrition, vol. 54, $1047-1058$.

15. Steel , R. G. and J. H. Torri. 1980. Principles and procedures of statistical , a biometrical approach. McGraw Hill Book Company, $2^{\text {nd }}$ Ed .

16. Welkie, G. W. and G. W. Miller. 2002 . Plant iron uptake physiology . In : Iron chelation in plants and soil microorganisms . Barton and Hemming (Eds) Academic Press New Yourk . 


\title{
تأثير الرش الورقى بالحديد المخلبى لنبات الفول البلاى

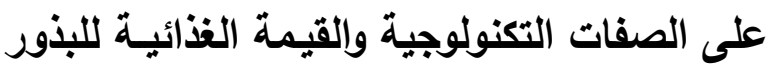

\author{
شـعبان محمد سـليمان \\ معرد بحوث تكنولوجيا الأغذية - مركز البحوث الزراعية - الجبزة
}

للحديد أهمية كبيرة فى تغذيـة النبات وهناك عوامل كثيرة تقلل من إمتصاصسه وكثيراً ما تظهر

أعراض نقصه على النبات رغم وجوده بنسبة كافية فى التربة .

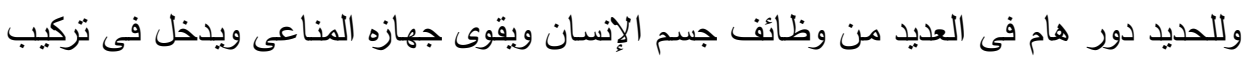

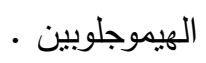

ولقد أجرى هذا البحث في مزرعة محطة بحوث سرس الليان بمحافظة المنوفية فى الموسمين

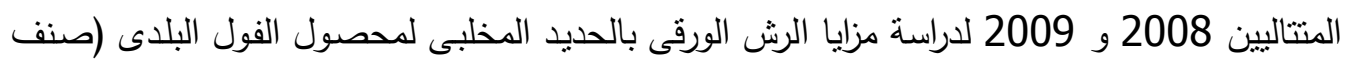

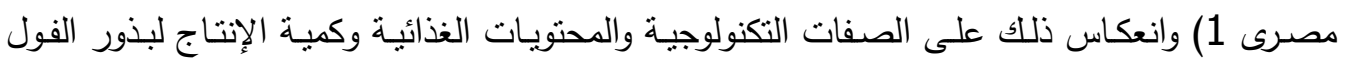

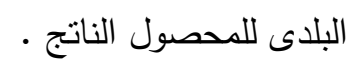

من أجل ذلك أستخدم محلول الإيدتا بتركيزى 0.08\% و 0.04\% مخلوطاً بـ او بدون محلول سكروز 0.4 \%ن اجن

وقد أظهرت نتائج البحث ان المعاملة (إيـتا 0.08\% + سكروز 0.4\% ) أحرزت افضل

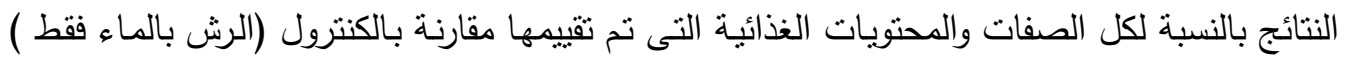

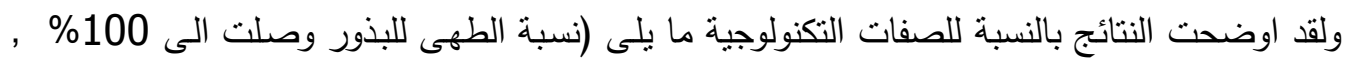

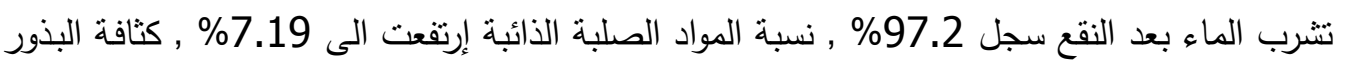
زادت الى لتى $\mathrm{gm} / \mathrm{cm}^{3} 1.62$

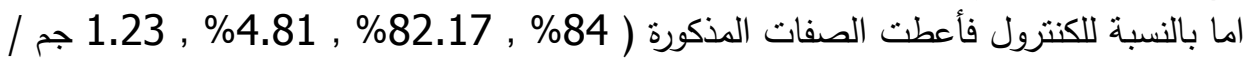

كما أوضحت النتائج : بالنسبة للمحتويات الغذائية الى تحسن مستوى البروتين الى 23.46\%

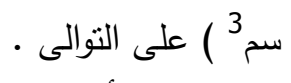
بينما فى حالة الكنترول 23.83\% . وأظهرت النتائج أن المحتويـات المعدنيـة للبذور كانت قيمها كالآتى : البوتاسيوم 1102.6

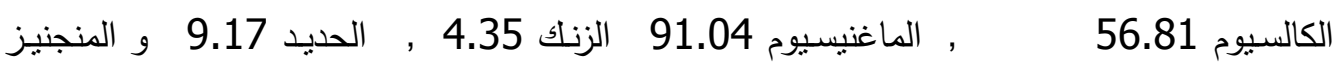
1.232 ملجم / 100 جم عينة (وزن جاف) على التوالى .

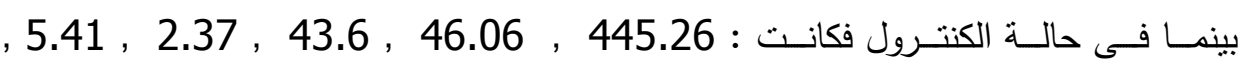

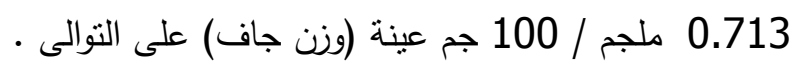

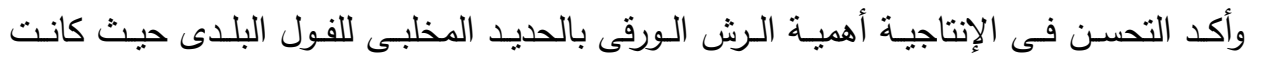

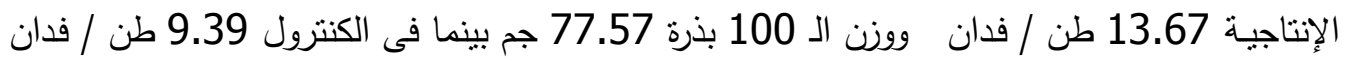

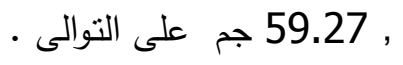

